\title{
M3E2 2019 - Towards a new economy in the public interest
}

\author{
Serhiy Semerikov ${ }^{1, *}$, Vladimir Soloviev ${ }^{1}$, Liubov Kibalnyk ${ }^{2}$, Oleksandr Chernyak $^{3}$, and Hanna Danylchuk ${ }^{2}$ \\ ${ }^{1}$ Kryvyi Rih State Pedagogical University, 54, Gagarina Ave., Kryvyi Rih, 50086, Ukraine \\ ${ }^{2}$ Cherkasy Bohdan Khmelnytskyi National University, Department of Economics and Business Modelling, Cherkasy, Ukraine \\ ${ }^{3}$ Taras Shevchenko National University of Kyiv, Department of Economic Cybernetics, 90-a, Vasylkivska str., Kyiv, 03022, Ukraine
}

\section{Introduction}

Nowadays in conditions of the world space transformation, the role of individual countries and their groups varies considerably. Priorities for ensuring sustainable growth of the world economy are distributed between countries and their groups unevenly. It is influenced by the global economic situation cycles, by potential and possibilities for realizing the achievements of information and technological progress, by the newest dominant tendencies of geographic and regional development, etc. As a result, some countries are ahead of others in the terms of economic growth. The specificity of the modern world economic system lies in the fact that global economic growth depends on the implementation of national economic potential, the ability to apply existing and acquired factors of economic dynamics at the level of individual countries.

One of the key characteristics of the structure of the modern world economy is the presence of a group of countries with emergent markets. The established classification of countries with growing (ascending, emergent) markets in the scientific literature is not formed, however, there are several research approaches regarding the content and criteria for identifying this group of countries. According to world-class scientists such as V. Kvint [1], T. Marois [2], M. A. Kose and E. S. Prasad [3], as well as according to international financial institutions, research centers (such as the British company FTSE, the corporation MSCI, the American financial company $\mathrm{S} \& \mathrm{P}$, the American financial information firm Dow Jones \& Company, Frontier Strategy Group, etc.), that deeply studied this problem, the formation of emergent markets in the world is associated with the presence of four main characteristics.

The essence of the first one is that this group includes countries with a large population, resource base and highvolume markets, that are the engines of economic development in different regions of the world. The second feature is the transitive type of society, and specifically implementation of internal economic and political reforms, the introduction of a policy of "openness" instead of a policy of strong state planning and control.
The next feature is high rate of economic growth, as a result of the country's active participation in international trade process. And the last feature is the significant growth of domestic and foreign investments due to the formation of a favorable environment for conducting business within the country.

At the same time, according to the experts of the Institute of Economics and Forecasting of the National Academy of Sciences of Ukraine, the issues of determining clear criteria for classification of countries belonging to this group remain unsolved, especially with relatively small area of the territory (less than 1 million square kilometers), as well as with limited market liquidity (in particular, Ukraine).

According to their opinion in Ukraine the problems of the intensification of the processes of emergence of the economy are hampered by the problems of low innovation activity of domestic enterprises, the volatility of foreign economic activity and the instability of the political situation. Therefore, we offer some steps towards the formation of well-developed emergency economics in Ukraine. Among them: the financing of technological parks through venture capital funds with a minimum state participation, which should be the guarantor of the reliability of private investment; the creation of a stock market, the forecasts of which will allow you to navigate the dynamics of stock quotes, that in the case of coincidence of real and predicted values will indicate the correctness of the decisions on investing in certain innovative enterprises; commercialization of scientific developments at the expense of enterprises and research institutions entering the international market of innovative technologies by joining the system of technology transfer INDEV of the State Committee for Investment and Development, etc.

Publications in the scientific literature prove a high level of interest in the theoretical and applied developments concerning the peculiarities and dynamics of the development of the countries of the emergent type. However, questions about the application of modern methods of investigation of the emergent properties of complex systems, sources and methods to the process of formation the emergent strategy of the country as a whole

* Corresponding author: semerikov@gmail.com 
and Ukraine in particular are still remain insufficiently studied.

In modern science, the achievements of modern mathematics, system analysis, decision-making theory, and so on are used to model and analyze the complex systems functioning. At the same time, the processes of globalization and integration, financial and economic instability cause the need to find out new tools that take into account elements of uncertainty, a significant number of risks and promote the efficiency of simulation processes.

The scientific contribution of modern scholars can be a guarantee for the improvement of the activities of various economic actors, the basis for the development of operational and strategic plans and programs of business and government activities. This collection of scientific works includes the research results of scientists aimed at improving the existing and developing new approaches in the modeling, management and monitoring of the emergent economy as a complex system.

\section{M3E2 2019 at a glance}

Monitoring, Modeling \& Management of Emergent Economy (M3E2) is a peer-reviewed international conference focusing on research advances and applications of nonlinear dynamics methods, econophysics and complex systems methodology of emergent economy.

The M3E2 Conference occupies contributions in all aspects of Computational Finance, Economics, Risk Management, Statistical Finance, Trading and Market Microstructure, (Deep) Machine Learning technologies and tools, paradigms and models, relevant to modern financial engineering and technological decisions in the modern age. There is urgent general need for principled changes in postclassic economy elicited by current models, tools, services, networks and IT communication.

M3E2 topics of interest:

- Complex cyberphysical systems, synergy, econophysics, economy of agents.

- Mathematical methods, models, informational systems and technologies in economics.

- Monitoring, modeling, forecasting and preemption of crisis in socio-economic systems.

- Models of global transformations.

- Experimental economics.

- The dynamics of emergent markets in post crisis period.

- Management of the state's economic safety and economic safety of economic agents.

- Modeling of hospitality sphere development.

- Prioritized ways of formation of the innovation model of Ukrainian economical development.

- The Global Challenges for Economic Theory and Practice in CEE Countries.

- (Deep) Machine Learning for prediction of emergent economy dynamics.

- Risk Management models in emergent economy.

This volume contains the papers presented at M3E2 2019: The 8th International Conference on Monitoring,
Modeling \& Management of Emergent Economy held on May 22-24, 2019 in Odessa.

There were 71 submissions. Each submission was reviewed by at least 3 , and on the average 3.1, program committee members. The committee decided to accept 52 papers. The program also includes 1 invited talks.

\section{M3E2 2019 program committee}

Vitalina Babenko, V. N. Karazin Kharkiv National University, Ukraine

Oleksandr Chernyak, Taras Shevchenko National University of Kyiv, Ukraine

Hanna Danylchuk, Bohdan Khmelnytsky National University of Cherkasy, Ukraine

Maryna Drobotova, Bohdan Khmelnytsky National University of Cherkasy, Ukraine

Giedre Dzemydaite, Vilnius University, Lithuania

Irina Georgescu, Academy of Economic Studies, Romania

Lidiya Guryanova, Simon Kuznets Kharkiv National University of Economics, Ukraine

Alexey Hostryk, Odessa National Economic University, Ukraine

Pavlo Hryhoruk, Khmelnytskyi National University, Ukraine

Liubov Kibalnyk, Bohdan Khmelnytsky National University of Cherkasy, Ukraine

Lyudmyla Kirichenko, Kharkiv National University of Radio Electronics, Ukraine

Arnold Kiv, Ben-Gurion University of the Negev, Israel

Konstantin Kovalchuk, National Metallurgical Academy of Ukraine, Ukraine

Oksana Kovtun, Staropolskia Szkola Wyższa w Kielcach (Centrum kształcenia w Czerkasach), Ukraine

Hanna Kucherova, Classic Private University, Ukraine

Nataliia Maksyshko, Zaporizhzhia National University, Ukraine

Andriy Matviychuk, Kyiv National Economic University named after Vadym Hetman, Ukraine

Tamara Merkulova, V. N. Karazin Kharkiv National University, Ukraine

Nikolaos Passalis, Tampere University, Finland

Lukas Pichl, International Christian University, Japan

Oleg Pursky, Kyiv National University of Trade and Economics, Ukraine

Serhiy Semerikov, Kryvyi Rih State Pedagogical University, Ukraine

Lyudmila Sergeyeva, Zaporizhzhia State Medical University, Ukraine

Yaroslav Shramko, Kryvyi Rih State Pedagogical University, Ukraine

Vladimir Soloviev, Kryvyi Rih State Pedagogical University, Ukraine

Viktoriia Solovieva, Kryvyi Rih Economic Institute of Kyiv National Economic University named after Vadym Hetman, Ukraine 
Valdemar Vitlinskyi, Kyiv National Economic University named after Vadym Hetman, Ukraine

Eugene Yakub, Odessa National Economic University, Ukraine

Nataliia Zachosova, Bohdan Khmelnytsky National University of Cherkasy, Ukraine

Pavel Zakharchenko, Berdyansk State Pedagogical University, Ukraine

\section{Conclusion}

The vision of the M3E2 2019 is provides a premier interdisciplinary platform for researchers, practitioners and educators to present and discuss the most recent innovations, trends, and concerns as well as practical challenges encountered and solutions adopted in the fields of emergent economy.

The conference has successfully performing forum to transferring and discussing research result among the researcher, students, government, private sector or industries. Participants and presenters from several countries such as Czechia, Italy, Israel, Lithuania, Poland, Slovenia, Ukraine have attended the conference to share their significant contribution in research related to Monitoring, Modeling \& Management of Emergent Economy.

We are thankful to all the authors who submitted papers and the delegates for their participation and their interest in M3E2 as a platform to share their ideas and innovation. Also, we are also thankful to all the program committee members for providing continuous guidance and efforts taken by peer reviewers contributed to improve the quality of papers provided constructive critical comments, improvements and corrections to the authors are gratefully appreciated for their contribution to the success of the conference.

We hope you enjoy this conference and meet again in more friendly, hilarious, and happiness of further M3E2 2020 .

The eighth instalment of M3E2 was organised by Kryvyi Rih State Pedagogical University, Ukraine (with support of the rector Yaroslav Shramko) in collaboration with the South Ukrainian National Pedagogical University named after K. D. Ushynsky, Ukraine (with support of the rector Aleksij Ya. Chebykin); Bohdan Khmelnytsky National University of Cherkasy, Ukraine (with support of the rector Oleksandr V. Cherevko); Information Systems Management Institute, Latvia (with support of the rector Deniss Djakons); Cardinal Stefan Wyszyński University in Warsaw, Poland (with support of the rector Stanisław Dziekoński); University of Vienna, Austria (with support of the rector Heinz W. Engl); Ben-Gurion University of the Negev, Israel (with support of the rector Chaim J. Hames); Taras Shevchenko National University of Kyiv, Ukraine (with support of the rector Leonid V. Hubersky); Belarusian State University, Republic of Belarus (with support of the rector Andrei D. Karol); Kyiv National Economic University named after Vadym Hetman, Ukraine (with support of the rector Dmytro G. Lukianenko); Cracow University of Economics, Poland (with support of the rector Andrzej Chochół); Vilnius University, Lithuania (with support of the rector Artūras Žukauskas).

\section{References}

1. Kvint, V.: Strategy for the Global Market: Theory and Practical Applications. Routlegde, New York (2016)

2. Marois, T.: Towards a Green Public Bank in the Public Interest. UNRISD Working Paper 2018-3. http://hdl.handle.net/10419/186113 Accessed 21 Mar 2019

3. Kose, M.A., Prasad, E.S.: Emerging Markets: Resilience and Growth amid Global Turmoil. Brookings Institution Press, Washington (2010) 